\title{
RELATION OF SERUM URIC ACID LEVEL AND ESSENTIAL HYPERTENSION AMONG PATIENTS WITHOUT METABOLIC SYNDROME
}

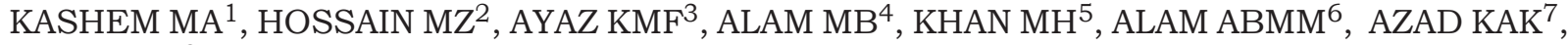 \\ KARIM ME ${ }^{8}$
}

\begin{abstract}
:
Objective: To find out and asses the association between hyperuricaemia and hypertension.

Methods: A case control study conducted in hypertension clinic, medicine and cardiac outpatient department of DMCH from December 2009 to November 2010 to evaluate association of hyperuricaemia and essential hypertension. A total of 51 hypertensive subjects aged 30 years and above were included as cases with same number of age \& sex matched normotensive subjects as control after excluding metabolic syndrome, renal impairment, clinical evidence of liver disease, IBD, malignant diseases, vascular diseases or history of taking relevant drugs by taking detailed history and thorough physical examination and appropriate laboratory investigations. Serum uric acid was measured in all study patients.

Results: The mean serum uric acid level was $5.8 \pm 1.5 \mathrm{mg} / \mathrm{dl}$ vs $4.5 \pm 1.2 \mathrm{mg} / \mathrm{dl}$ in case and control patients respectively. A total of 13 (25.4\%) patients in cases and 5 (9.8\%) patients in control had hyperuricaemia (Odds Ratio 3.15, $p<0.05$ ). So, the number of hyperuricaemic person \& mean serum uric acid level were significantly higher in hypertensive Cases, as Compared to Those of Healthy Normotensive Control.
\end{abstract}

Keywords: Essential hypertension, Serum Uric Acid, Hyperuricaemia

J Dhaka Med Coll. 2011; 20(1) : 5-8.

\section{Introduction:}

Hypertension is very common among the population, affecting 1 in 4 adults worldwide ${ }^{1}$. Hypertension and its complications are one of the leading causes of death and disability in developed countries as well as developing countries like Bangladesh. Estimated incidence of HTN in Bangladesh is $20.3 \%$, according to a nationwide population based study, recently done by Bangladesh Society of Medicine, financed by WHO.

It is a recognized risk factor of stroke, cardio vascular disease and is a leading cause of chronic kidney failure ${ }^{2}$, is multi factorial in origin, $95 \%$ of them are primary or essential hypertension, where the exact causes are yet not known ${ }^{3}$. Whereas the cases of hypertension presents at an earlier age group and are difficult to treat, usually have identifiable cause, are secondary hypertension.

It has been thought that Serum uric acid (SUA) have an association with hypertension and plays role in the pathogenesis of hypertension. Several evidences suggest that increased serum uric acid may be a significant modifiable risk factor for developing hypertension. Limited information is available concerning the prevalence of hyperuricaemia among hypertensive. However, one study conducted in Australia, showed a prevalence rate of

1. Dr. Md. Abul Kashem, Registrar, Dept. of Medicine, SSMC.

2. Dr. Mohammad Zaid Hossain, Assistant Professor, Dept. of Medicine, DMC.

3. Dr. Khan Md. Fariduddin Ayaz, Assistant Professor, Dept. of Medicine, DMC.

4. Dr. Md. Babrul Alam, Resident Physician, NIKDU.

5. Dr. Mosaraf Hossain Khan, Registrar, Dept. of Nephrology, DMC.

6. Dr. ABM Mobassher Alam, Asstt Registrar, NIKDU

7. Prof. Khan Abul Kalam Azad, Professor of Medicine, DMC

8. Prof. Md. Enamul Karim, Professor of Medicine, DMC.

Correspondence : Dr. Md. Abul Kashem, Registrar, Dept. of Medicine, SSMC. 
hyperuricaemia of $31 \%$ among untreated hypertensive subjects ${ }^{4}$, as compared to that of $10 \%$ among healthy general population ${ }^{5}$.

Serum uric acid was first noted to be associated with increased BP by Frederick Mohamed in the $1870 s^{6}$. Animal model experiments demonstrate that increased serum uric acid causes increased BP that initially is reversible but becomes irreversible, salt sensitive, and uric acid independent over time. The mechanism include inflammatory and vascular changes in the renal microcirculation ${ }^{7}$, activation of the reninangiotensin system, and endothelial dysfunction.

Although hypertension and its complications are one of the leading causes of death and disability in Bangladesh, still lagging behind in detecting, treating and optimum control of blood pressure in the community people. Rather early detection, and attempt to prevent or at best delaying the appearance of hypertension by identifying association and risk factor modification can be an option along with drug treatment of hypertension is feasible. Traditional modifiable risk factors are now being evaluated but there is a pressing need to identify additional treatable risk factors that are easily measured and highly prevalent in general population. Hyperuricaemia may be such type of potentially modifiable risk factor. It may be possible to reduce the incidence of hypertension by curbing down hyperuricaemia if it proved to related to hypertension.

\section{Materials and Methods:}

This case control study conducted in hypertension clinic in medicine and cardiac out patient department clinic of Dhaka Medical College Hospital from December 2009 to November 2010 to evaluate association of hyperuricaemia and essential hypertension. A total of 51 hypertensive subjects aged 30 years and above were included as cases (group I) with same number of age \& sex matched normotensive subjects as control (group II) after excluding metabolic syndrome, renal impairment, clinical evidence of liver disease, IBD, malignant diseases, vascular diseases or history of taking relevant drugs by taking detailed history and thorough physical examination and appropriate laboratory investigations. Serum uric acid was measured in all study patients.

\section{Results:}

The mean age of group I was $50.1 \pm 10.1$ years and $47.5 \pm 8.9$ years of that of group II. Most of the patients belonged to $41-50$ years in both groups. Male, female ratio was 1.1:1.

Table I

Age distribution of the study patients

\begin{tabular}{lccc}
\hline Age in years & $\begin{array}{c}\text { Group I } \\
(\mathrm{n}=51)\end{array}$ & $\begin{array}{c}\text { Group II } \\
(\mathrm{n}=51)\end{array}$ & $\begin{array}{c}\mathrm{P} \\
\text { value }\end{array}$ \\
\hline $30-40$ & $11(21.6)$ & $15(29.4)$ & \\
$41-50$ & $19(37.3)$ & $20(39.2)$ & \\
$51-60$ & $15(29.4)$ & $9(17.6)$ & \\
$61-70$ & $4(7.8)$ & $6(11.8)$ & \\
$>70$ & $2(3.9)$ & $1(2.0)$ & \\
Mean \pm SD & $50.1 \pm 10.1$ & $47.5 \pm 8.9$ & $0.186^{\mathrm{ns}}$ \\
Range & $(36-80)$ & $(32-70)$ & \\
\hline
\end{tabular}

Figures within parentheses indicate percentage ns $=$ not significant

$P$ value reached from unpaired test

The mean systolic BP was $153.3 \pm 10.9 \mathrm{mmHg}$ and $109.5 \pm 10.1 \mathrm{mmHg}$ in group I and group II and the mean diastolic BP was $95.5 \pm 6.6 \mathrm{mmHg}$ and $74.2 \pm 7.0 \mathrm{mmHg}$ in group I and group II respectively and the mean systolic and diastolic BP difference were statistically significant $(p<0.05)$ between two groups.

Table-II

Distribution of study patients according to mean serum uric acid level

\begin{tabular}{lccccccc}
\hline Uric acid $(\mathrm{mg} / \mathrm{dl})$ & \multicolumn{3}{c}{ Group I $(\mathrm{n}=51)$} & & \multicolumn{3}{c}{ Group II $(\mathrm{n}=51)$} \\
\cline { 2 - 4 } Mean $\pm \mathrm{SD}$ & Male & Female & Total & & Male & Female & Total \\
\hline & $6.0 \pm 1.4$ & $5.5 \pm 1.3$ & $5.8 \pm 1.5$ & & $4.8 \pm 1.4$ & $4.2 \pm 1.2$ & $4.5 \pm 1.2$ \\
Range & $(3.0-7.8)$ & $(3.0-7.4)$ & & & & & \\
\hline
\end{tabular}

$P$ value 0.001

$\mathrm{P}$ value reached from unpaired test 
Relation of Serum Uric Acid Level And Essential Hypertension

Kashem MA et al

Table III

Distribution of the study patients according to Hyperuricaemia in male \& female (SUA ${ }^{3} 7.0 \mathrm{mg} / \mathrm{dl} \mathrm{for}$ male, $\geq 6.0 \mathrm{mg} /$ dl for female)

\begin{tabular}{llcccccc}
\hline Hyper- & \multicolumn{3}{c}{ Male } & & \multicolumn{3}{c}{ Female } \\
\cline { 7 - 8 } uricaemia & Group I & Group II & Odds & & Group I & Group II & Odds \\
\hline & $(\mathrm{n}=27)$ & $(\mathrm{n}=26)$ & Ratio & & $(\mathrm{n}=24)$ & $(\mathrm{n}=25)$ & Ratio \\
& $7(25.9)$ & $3(11.5)$ & 2.68 & & $6(25.0)$ & $2(8.0)$ & 3.83 \\
\hline
\end{tabular}

Figures within parentheses indicate percentage

Odds Ratio (total) 3.15, P Value 0.038,

$\mathrm{P}$ value reached from Chi square test

The number of hyperuricaemic subjects was significantly higher in case group as compared to control $(25.4 \%$ vs $9.8 \%)(\mathrm{p}<0.05$, OR 3.15$)$. In addition, the mean serum uric acid level was $5.8 \pm 1.5 \mathrm{mg} / \mathrm{dl}$ vs $4.5 \pm 1.2 \mathrm{mg} / \mathrm{dl}$ in case and control patients respectively, which was significantly higher case group $(\mathrm{p}<0.05)$.

\section{Discussion:}

This case control study reflected the association of hyperuricaemia with essential hypertension. In this present study, observed difference of hyperuricaemia between cases and control well corresponds with Garrick et al. ${ }^{4}$ where they observed $31 \%$ of their study patients had hyperuricaemia with hypertension. The mean uric acid in cases were close to that of Perlstein et al. ${ }^{8}$ and Strasak et al. ${ }^{9}$, they found mean uric acid level $5.8 \pm 0.9 \mathrm{mg} / \mathrm{dl}$ and $5.7 \pm 1.2 \mathrm{mg} / \mathrm{dl}$ respectively, however, higher mean were observed by Feig et al. ${ }^{10}$, where they found mean uric acid was $6.9 \mathrm{mg} / \mathrm{dl}$ in their study patients. Mean age of the patients was close to those of Mellen et al. ${ }^{11}$, where the authors observed the mean age was 53.3 years. Forman et al. ${ }^{12}$ observed age range of the patients was 53 to 68 years. Krishnan et al. ${ }^{13}$ have observed mean age of the patients was $44.7 \pm 5.8$ years and Forman, et al. ${ }^{12}$ found median age was 43.2 years. Strasak et al. ${ }^{9}$ and Perlstein et al. ${ }^{8}$ observed mean age of their study patients were $41.6 \pm$ 14.7 years and $41.7 \pm 9.2$ years respectively. Male female ratio of this study patients was lower than that of Feig et al. ${ }^{10}$, where they showed male female ratio was $1.5: 1$, which indicates that male was predominant in their study. Feig et al. ${ }^{10}$ found the mean systolic and diastolic BP were $139 \mathrm{mmHg}$ and $83 \mathrm{mmHg}$ respectively in their study patients. Krishnan, et al. ${ }^{13}$ showed the mean systolic and diastolic $\mathrm{BP}$ were $123.1 \pm 8.6 \mathrm{mmHg}$ and $82.3 \pm 5.4 \mathrm{mmHg}$ respectively in their patients. Strasak et al. ${ }^{9}$ observed in their study that mean systolic blood pressure was $132.0 \pm 18.8 \mathrm{mmHg}$ and diastolic blood pressure was $81.610 .8 \mathrm{mmHg}$. Mellen et al. ${ }^{11}$ showed mean systolic blood pressure was $113.8 \mathrm{mmHg}$ and diastolic blood pressure 70.2 mmHg. Similar mean blood pressure obtained by Perlstein et $\mathrm{al}^{8}$; majority of the study findings is consistent with the present study regarding the mean blood pressure.

\section{Conclusion:}

The number of hyperuricaemic person $\&$ mean serum uric acid level were significantly higher in hypertensive cases, as compared to those of healthy normotensive control. Therefore, it can be concluded that hyperuricemia is significantly associated with hypertension and hyperuricaemia-hypertension risk relationship is present in patients irrespective of metabolic syndrome. Further larger scale study needed for assessment of association with strength of association and risk relationship between hyperuricaemia and hypertension. Serum uric acid level could be a good screening tool to aid the risk stratification of individuals at risk of developing hypertension, if these findings are confirmed by larger scale studies.

\section{Reference :}

1. Colledge NR, Walker BR, Ralston SH. eds. Davidson's principles and practice of medicine. $21^{\text {st }}$ ed. Edinburg: Elsevier Churchill Livingstone; 2010 . 
2. Pierdomenico SD, Di Nicola M, Esposito AL, et al. Prognostic Value of Different Indices of Blood Pressure Variability in Hypertensive Patients. Am J Hypertension 2009; 22(8): 842-7.

3. Carretero OA, Oparil S. Essential hypertension. Part I: definition and etiology. Circulation. 2000; 101(3): 329-35.

4. Garrick Bauer RGE, Ewan CE, Neale FC. Serum Uric Acid in Normal and Hypertensive Australian Subjects: From a Continuing Epidemiological Survey on Hypertension Commenced in 1955. Internal Med J 2008; 2(4): 351-6.

5. Lonsoonthorn VB, Dhanamum M, Williams B. Prevalance of Hyperuricaemia \& its relationship with metabolic syndrome in Thai adults receiving annual health exams. Arch Med Res 2009; 37: 883-9.

6. JD Swales. Manual of hypertension. Oxford: Blackwell Science. 1995.

7. Mazzali M. et al. Hyperuricaemia induces a primary renal arteriolopathy in rats by a blood pressure-independent mechanism'. Am J Renal Physiol 2002; 282; 991-7.
8. Perlstein, TS. et al. Uric Acid and the Development of Hypertension; The Normative Aging Study. Hypertension. 2006; 48: 1031-36.

9. Strasak, A. et al. Serum Uric Acid and Risk of Cardiovascular Mortality: A Prospective Long-Term Study of 83,683 Austrian Men. Clin Chem. 2008; 54(2): 273-84.

10. Feig DI, Soletsky B, Johnson RJ. Effect of Allopurinol on Blood Pressure of Adolescents with Newly Diagnosed Essential Hypertension. J Am Med Assoc 2008; 300(8); 924-32.

11. Mellen PB, et al. Serum Uric Acid Predicts Incident Hypertension in a Biethnic Cohort The Atherosclerosis Risk in Communities Study. Hypertension. 2006; 48; 1037-42.

12. Forman JP, Choi H, Curhan GC. Plasma Uric Acid Level and Risk for Incident Hypertension Among Men. J Am Soc Nephrol. 2007; 18: 287-292.

13. Krishnan E, Kwoh CK, Schumacher HR, Kuller L. Hyperuricaemia and Incidence of Hypertension among Men Without Metabolic Syndrome. Hypertension. 2007; 49: 298-303. 